\title{
KEANEKARAGAMAN JENIS KANTONG SEMAR (NEPENTHES SPP.) DI TUTUPAN LAHAN SEMAK BELUKAR DAN HUTAN SEKUNDER DUSUN GEMURUH KECAMATAN SELAKAU TIMUR KABUPATEN SAMBAS
}

\author{
(Species Diversity of Picther Plant (Nepenthes spp.) In Shurb Land Cover and Secondary \\ Forest In Gemuruh East Selakau Sub-district Sambas Regency)
}

\author{
M. Sapaat Amanda, Dwi Astiani, Abdurrani Muin \\ Fakultas Kehutanan Universitas Tanjungpura, Jalan Daya Nasional Pontianak, 78124 \\ Email: Sapaatfahutan@gmail.com
}

\begin{abstract}
Tropical forests have a complex vegetation structure, which supports habitat for various types of plant species. But the opening of forest land cover can affect it. Picther plan (Nepenthes spp.) is one type of plant that is in the area of tropical rainforest. Nepenthes spp. are a unique type of flora in terms of color and shape which makes this plant very desirable to be used as an ornamental plant that has quite good economic value. The purpose of this study was to determine the species diversity of Nepenthes spp. from two land cover. This study uses a double plot with sub-plots with a basic field survey method of laying plots using purposive sampling. The results of the study found four types of Nepenthes spp. in shrub land cover and only one species in secondary forest. The species found is N. ampullaria Jack, N. gracilis Korth, $N$. mirabilis and N. rafflessiana. Each index of diversity is $N$. ampullaria Jack 0.1253, $N$. mirabilis (Lour) Druce 0.1004, N. gracilis Korth 0.0314, N.rafflesiana Jack 0.0105. Nepenthes spp. dispersion index on shrub land cover is group and in secondary forest is uniform. This area is more commonly found Nepenthes spp. and its dominance is higher in bush cover than in secondary forests.
\end{abstract}

Keywords: Nepenthes spp., Secondary forests, Shrubs, Species diversity

\section{PENDAHULUAN}

Kantong semar (Nepenthes spp.) memiliki ciri yang sangat khas yaitu mempunyai kemampuan untuk menangkap serangga yang dijadikan sebagai nutrisi untuk membantun pertumbuhan dan perkembangannya, ditandai dengan terbentuknya kantong pada ujung daunnya (Perwira, 2007). Selain keunikannya yang mampu untuk menjebak serangga keunikan yang lain dari tumbuhan ini adalah dari bentuk kantong yang bervariasi, ukuran serta corak dari daun dan kantongnya (Fathul et al. 2007).

Di alam, kantong semar dapat tumbuh pada ketinggian 0-3000 m dpl. Kebanyakan dari tumbuhan kantong semar dapat hidup di teresterian di tanah gambut, berpasir, berkapur, celah bebatuan, serasah daun, ataupun tanah gunung. Penyebaran kantong semar dimulai dari Madagaskar,China bagian selatan, Asia Tenggara, Australia bagian Utara Kepulauan Seychelles, dan Indonesia. Di Indonesia terdapat 64 jenis kantong semar, yang 59 diantaranya berstatus endemik 
(Handayani, 2008). Penyebaran kantong semar di Indonesia terdapat di pulau Sumatera (34 jenis, 29 di antaranya endemik). Jawa (3 jenis, 2 di antaranya endemik). Sulawesi (11 jenis, 7 di antaranya endemik) Maluku (3 jenis) dan Papua (11 jenis, 7 diantarnya endemik. Di Kalimantan sendiri terdapat 32 jenis kantong semar dari 64 jenis yang ada di Indonesia. Sampai saat ini tercatat terdapat 103 jenis Kantong semar yang sudah dipublikasikan (Firstantinovi dan Karjono, 2006).

Dusun Gemuruh merupakan dusun yang secara administrasi berada di Desa Selakau Tua. Dusun Gemuruh terdapat semak belukar dan hutan sekunder yang cukup luas. Dulunya di Selakau Timur terdapat hutan primer karena masyarakat dusun Gemuruh khusunya menggantungkan hidupnya pada hutan maka seiring berjalannya waktu hutan tersebut menjadi rusak. Hal ini diperparah lagi dengan adanya aktifitas manusia yang bersifat merusak lingkungan seperti penambangan emas tanpa izin (PETI), pembalakan liar, dan ladang berpindah dengan sistem tebang habis bakar.

Perambahan tutupan lahan dapat mempengaruhi keberadaan kantong semar di Selakau Timur khususnya di Dusun Gemuruh selanjutnya kurangnya pengetahuan masyarakat tentang kantong semar dapat menyebabkan terancam punah. Kondisi seperti ini akan sangat memprihatinkan jika terus menurus terjadi maka keberadaan kantong semar akan menjadi punah. Namun bila keberadaannya cukup, dapat juga diperoleh manfaat dari tumbuhan tersebut.
Itulah alasannya mengapa perlu dilakukan penelitian kantong semar di Selakau Timur.

\section{METODE PENELITIAN}

Penelitian ini dilaksanakan selama 1(satu) bulan efektif lapangan terhitung mulai dari 5 Februari - 5 Maret 2018. Penelitian ini dilakukan dengan metode survey lapangan, pengambilan sampel penelitian menggunakan petak ganda. Peletakan petak berdasarkan purposive sampling atau sengaja diletakan pada lokasi yang terdapat kantong semar. Eksplorasi dan pengambilan sampel dilakukan dengan 6 petak contoh yaitu empat di semak belukar dan dua dihutan sekunder. Masing-masing petak contoh berukuran $20 \mathrm{~m}$ x $20 \mathrm{~m}$ peletakan petak berdasarkan survey awal pada lokasi Dusun Gemuruh Kecamatan Selakau Timur dengan indikasi melihat keberadaan kantong semar. Pada petak $20 \mathrm{~m}$ x $20 \mathrm{~m}$ terdapat sub petak $5 \mathrm{~m}$ x $5 \mathrm{~m}$.

Tujuan dari peletakan petak ini adalah untuk mempermudah peneliti untuk mengamati tumbuhan kantong semar dan vegetasi lain yang terdapat didalam petak tersebut. Setiap jenis kantong semar yang ditemukan dicatat nama dan jumlah individunya. Untuk mengidentifikasi jenis kantong semar parameter yang diamati adalah berupa foto-foto, karakteristik morfologi, batang, kantong, akar, tendril warna, serta data yang didapatkan di lapangan akan diidentifikasi dengan menggunakan buku pedoman determinasi: Nepenthes yang Unik. Data yang diamati dalam penelitian ini yaitu, jenis kantong semar, jumlah jenis, jumlah individu masing-masing jenis kantong semar. 
kondisi tempat tumbuh, suhu udara, kelembaban udara, kelembaban tanah, $\mathrm{pH}$ tanah, intensitas cahaya dan lain-lain. Analisis data dari jenis-jenis kantong semar dapat dihitung dengan menggunakan rumus, Indek Nilai Penting (INP), Indeks keanekaragaman jenis, Indeks dominansi, Indeks kemerataan jenis dan indeks morista.

\section{a. Indek Nilai Penting}

Indeks nilai penting diperoleh dengan menjumlahkan parameter Kerapatan Relatif (KR) dan Frekuensi Relatif (FR). Untuk mendapatkan nilai parameter tersebut menggunakan rumus sebagai berikut:

$\mathrm{INP}=\mathrm{KR}+\mathrm{FR}$

Keterangan : INP =Indek Nilai Penti

$\mathrm{KR}=$ Kerapatan Relatif

$\mathrm{FR}=$ Frekuensi Relatif

\section{b. Kerapatan Relatif}

Kerapatan menunjukan jumlah suatu jenis tumbuhan kantong semar pada setiap petak contoh.

$\operatorname{Kerapatan}(\mathrm{K})=\frac{\text { Jumlah Individu suatu jenis }}{\text { Luas contoh }}$

$\operatorname{Kerapatan}(\mathrm{KR})=$

$\frac{\text { Kerapatan dari suatu jenis }}{\text { Kerapatan seluruh jenis }} 100 \%$

\section{c. Frekuensi Relatif}

Frekuensi merupakan perbandingan banyaknya petak yang terisi oleh suatu jenis tumbuhan terhadap jumlah petak seluruhnya, yang biasanya dinyatakan dengan persen.

Frekuensi

$(\mathrm{F})=$

Jumlah petak ditemukannya suatu jenis Jumlah petak seluruhnya

Frekuensi

$(\mathrm{FR})=$

$\frac{\text { Frekuensi suatu jenis }}{\text { Frekuensi seluruh jenis }} \times 100 \%$

d. Indeks Dominansi $(C)$
Untuk menentukan dominansi suatu jenis yang terpusat dalam komunitas dapat digunakan rumus Odum (1993).

$\mathrm{c}=\sum\left(\frac{n i}{\mathrm{~N}}\right)^{2}$

Dimana :

$\mathrm{C}=$ Indeks Dominansi.

$n . i=$ Nilai Penting dari Indeks i.

$\mathrm{N}=$ Total Nilai Penting.

Kriteria Indek Dominansi adalah:

$0<\mathrm{C}<0,5=$ Dominansi jenis rendah

$0,5<\mathrm{C}<1=$ Dominansi jenis sedang

$\mathrm{C}>1=$ Dominansi jenis tinggi

e. Indeks Keanekaragaman Jenis $(\overline{\boldsymbol{H}})$

Merupakan suatu indeks keanekaragaman secara keseluruhan dalam suatu komunitas atau habitat yang dapat ditentukan dengan rumus ShanonWiener (Ferianita Fachrul, M. 2007) sebagai berikut:

$\bar{H}=-\sum\left(\frac{n i}{N}\right) \log \left(\frac{n i}{N}\right)$

Dimana :

$\bar{H}=$ Indek keanekaragam jenis keseluruhan .

$\mathrm{ni}=$ jumlah individu .

$\mathrm{N}=$ jumlah individu seluruh jenis.

Besarnya indeks keanekaragaman jenis menurut Shanon-Wiener didefinisikan sebagai berikut.

Nilai $\bar{H}>3=$ melimpah tinggi.

Nilai $\bar{H} 1 \leq \bar{H} \leq 3=$ sedang melimpah.

Nilai $\bar{H}<1=$ sedikit atau rendah.

\section{f. Indeks Kelimpahan Jenis (e)}

Indeks kelimpahan jenis dipengaruhi oleh keaneakragaman jenis dan jumlah jenis. Digunakan untuk mengetahui kelimpahan suatu jenis pada area. Indeks kelimpahan jenis dihitung dengan rumus Evenness menurut Odum, 1993 : 4 sebagai berikut 


$$
e=\frac{\bar{H}}{\log s}
$$

Dimana :

e $=$ Indeks Kelimpahan Jenis

$\bar{H}=$ Indeks keanekaragaman Jenis

$\mathrm{S}=$ Jumlah Jenis

Indeks kelimpahanan jenis berkisar antara 0-1, jika e > 1, maka seluruh jenis yang ada memiliki kelimpahan yang sama atau merata, sedangkan jika e $<1$, maka seluruh jenis yang ada kelimpahannya tidak merata.

\section{g. Indeks Morisita (Id)}

Indeks morista dimaksudkan untuk menentukan penyebaran dalam suatu komunitas, karena suatu tempat tumbuh masing-masing jenis tumbuhan memiliki suatu bentuk distribusi tersendiri (Michael, 1994) rumus yang digunakan adalah.

$\mathrm{Id}=\frac{N \sum \mathrm{x}^{2}-\sum x}{\left(\sum x\right)^{2}-\sum x}$

Dimana :

Id = Indeks Morista

Tabel 1. Rekapitulasi Jumlah Individu, Kerapatan/ Ha, Indek Nilai Penting, Keanekaragaman Jenis, Dominansi Jenis, Kelimpahan Jenis dan Indeks Morisita. (Recapitulation Total of Individual, Density/Ha, Index of Important Values, Species Diversity, Species Dominance, Species Average and Index of Morisita).

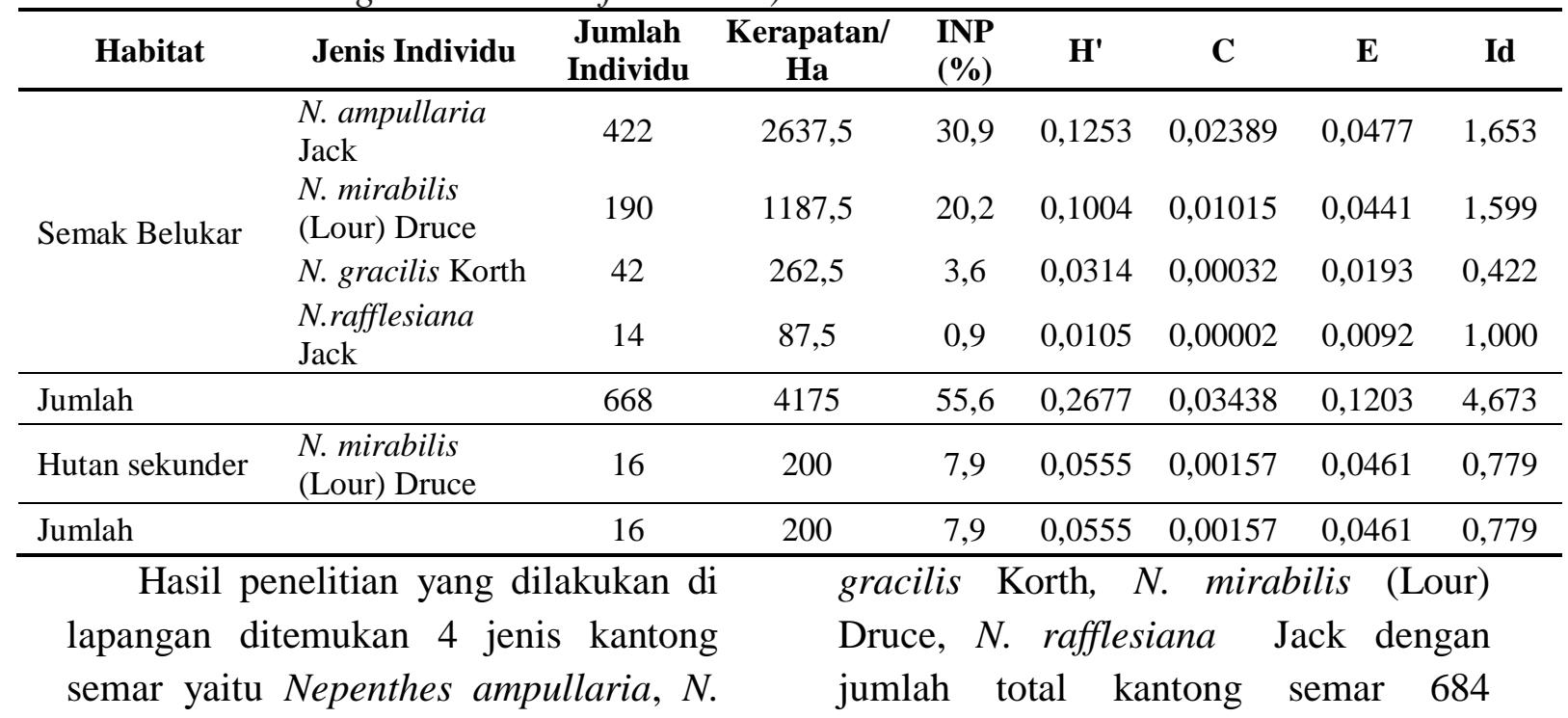


individu. Pada tutupan lahan semak belukar dengan areal seluas 0,16 ha $N$. ampullaria merupakan jenis yang memiliki kerapatan paling tinggi yaitu 2637,5 individu/ha dan kerapatan relatif 17,9 dan N. mirabilis (Lour) Druce dengan kerapatan 1187,5 individu/ha dan kerapatan relatif 8,1 . Kehadiran spesies yang mendominasi pada suatu kawasan merupakan petunjuk bahwa kantong semar menemukan tempat tumbuh yang ideal atau sesuai terhadap tempat tumbuh di tutupan semak belukar. Spesies yang dapat dikatakan mendominasi pada suatu lokasi apabila jenis tersebut berjumlah besar dan tersebar merata hampir di seluruh kawasan.

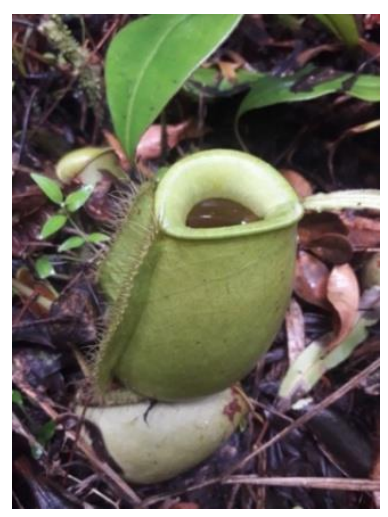

a

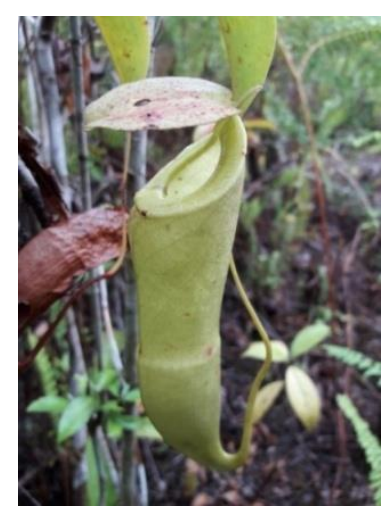

$\mathrm{b}$

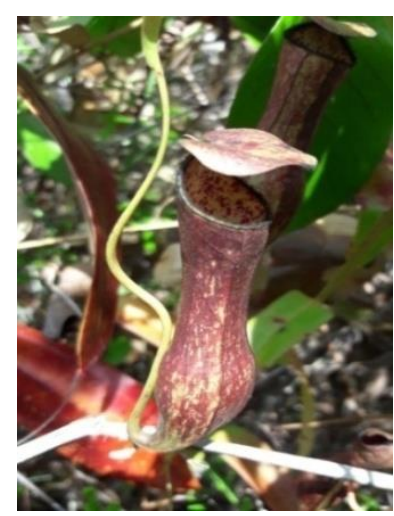

c
Nilai yang paling rendah adalah jenis $N$ rafflesiana Jack 87,5 individu/ha dan kerapatan relatif 0,6 , sementara itu pada hutan sekunder dengan luas areal 0,08 ha jenis $N$. mirabilis (Lour) Druce memiliki kerapatan 200 individu/ha dan kerapatan relatif 2,4.

Kerapatan kantong semar pada dua habitat memiliki perbedaan. Hal ini diakibatkan adanya kondisi tempat tumbuh yang berbeda untuk setiap jenisnya. Tingginya kerapatan pada semak belukar membuktikan bahwa pada semak belukar dengan kondisi agak terbuka lebih cocok untuk tempat tumbuh kantong semar. Keempat jenis kantong semar tersebut dapat dilihat pada gambar dibawah ini.

Gambar 1. Jenis-jenis Nepenthes yang di temukan di lokasi penelitian yaitu a). Nepenthes ampullaria Jack, b) Nepenthes mirabilis, c) Nepenthes gracilis dan d). Nepenthes rafflessiana. (The species of Nepenthes found at the research location a). Nepenthes ampullaria Jack, b). Nepenthes mirabilis, c) Nepenthes gracilis and d). Nepenthes rafflessiana.)

Jenis kantong semar ampullaria Jack merupakan jenis yang paling banyak ditemukan pada tutupan lahan semak belukar dengan kondisi agak terbuka. Hal membuktikan bahwa kantong semar lebih cocok pada kondisi tanah bergambut dengan sinar matahari langsung. Jumlah dan jenis kantong semar yang ditemukan di semak belukar berbeda dengan yang ditemukan oleh 
Dino (2016) pada kawasan Danau Sebedang Kabupaten Sambas. Pada lokasi penelitian Dusun Gemuruh Kecamatan Selakau Timur jenis yang ditemukan ada empat jenis sedangkan pada kawasan Danau Sebedang ada dua jenis yaitu N. mirabilis dan N. gracilis. Perbedaan jumlah dan jenis yang ditemukan dipengaruhi oleh kondisi lingkungan dan tempat tumbuh yang berbeda. Perbedaan jumlah jenis dan individu kantong semar yang ditemukan pada masing-masing petak pengamatan

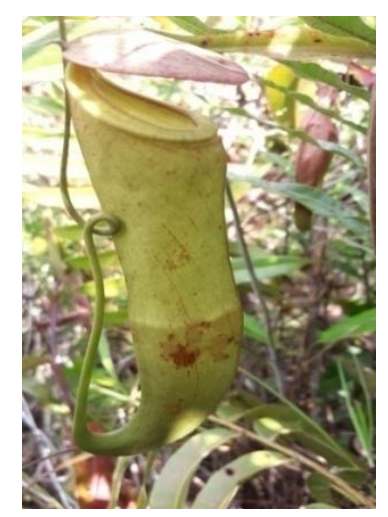

a

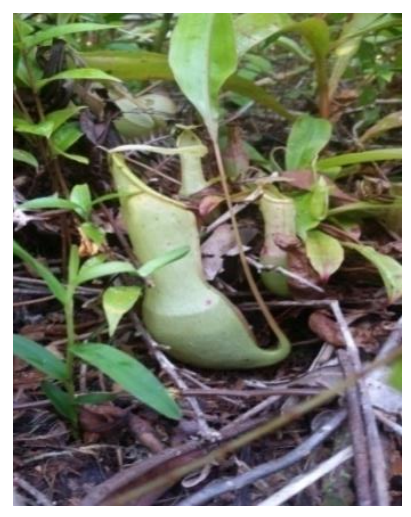

b dikarenakan adanya variasi kondisi tempat tumbuh pada setiap tutupan lahan. Oleh karena itulah jenis yang ditemukan pada lokasi penelitian beragam jenisnya. Selain variasi jenis yang ditemukan pada lokasi penelitian, didapat juga variasi pada bentuk kantong. Nepenthes mirabilis merupakan jenis kantong semar yang memiliki variasi bentuk kantong yaitu bentuk corong, pinggang dan slinder. Seperti pada gambar dibawah ini.

Gambar 2. Variasi bentuk kantong pada Nepenthes. a). Bentuk kantong corong, b). Bentuk kantong pinggang, c). Bentuk kantong silinder (Variation of pouch shape in Nepenthes. a). Funnel bag shape, b). Shape of waist bag, c). Cylindrical shape).

Selain dari bentuk kantong yang bervariasi saat ditemukan dilokasi penelitian, N. mirabilis (Lour) Druce memiliki variasi warna yang berbeda. Variasi warna yang ditemukan diduga karena ada faktor tutupan vegetasi dan penerimaan sinar matahari. Warna yang ditemukan adalah warna hijau polos dan warna hijau kemerah-merahan. Perbedaan warna tersebut dapat dilihat pada gambar berikut ini. 


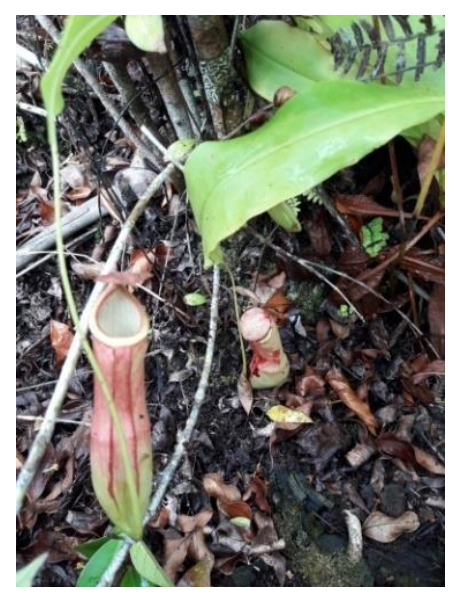

a

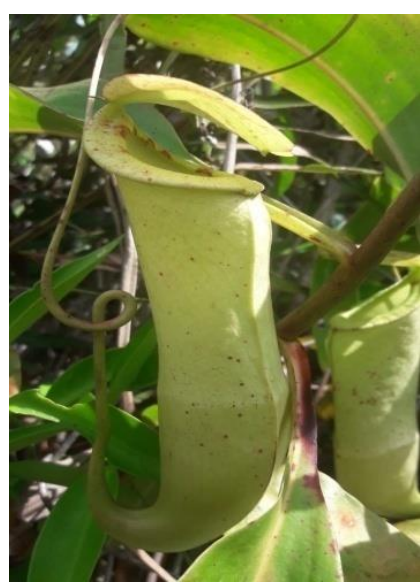

b

Gambar 3. Variasi warna N. mirabilis (Lour) Druce. (Color variations N. mirabilis (Lour) Druce).

Nepenthes gracilis Korth yang merah bercampur hijau dan coklat ditemukan di lapangan pada tutupan muda. Perbedaan warna tersebut dapat lahan semak belukar memiliki tiga variasi warna yaitu warna coklat tua,

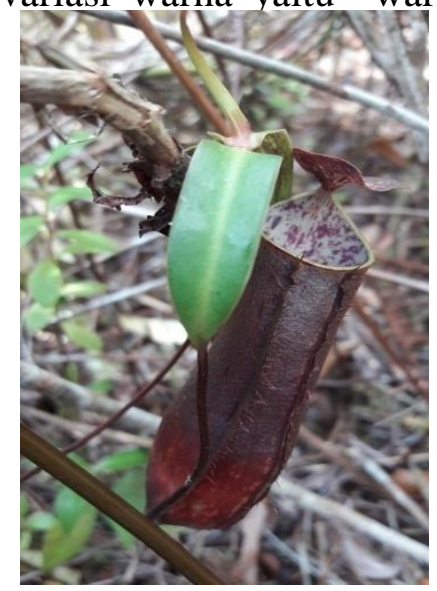

a

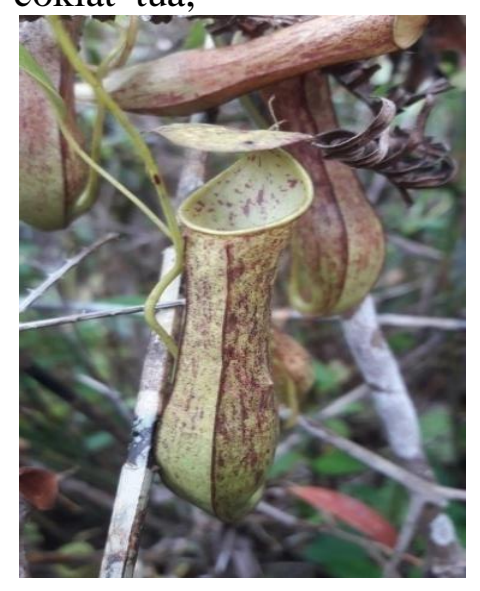

b

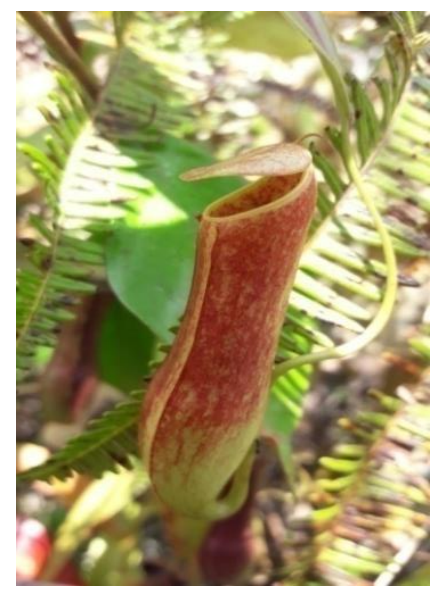

c

Gambar 4. Variasi warna N. gracilis Korth. (Color variations N. gracilis)

Selain jenis kantong semar mirabilis (Lour) Druce, N. gracilis Korth dan $N$. ampullaria Jack jenis N.rafflesiana Jack juga memiliki variasi warna yang juga tidak kalah menariknya dengan jenis lainnya yang ditemukan dilapangan. Variasi warna yang ditemukan untuk jenis kantong semar rafflesiana Jack dilokasi penelitian memiliki dua variasi warna yaitu berwarna lurik coklat dan merah muda. 


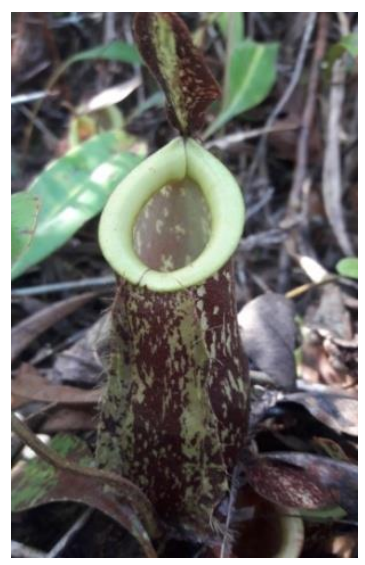

a

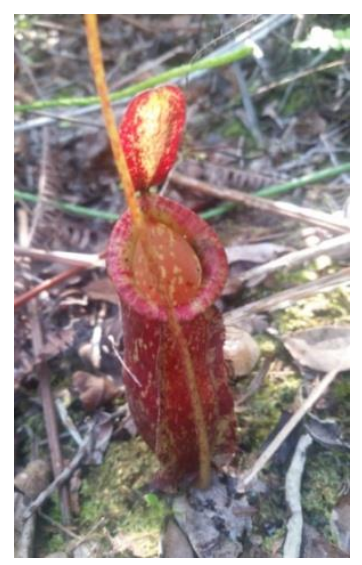

b

Gambar 5. Variasi warna N.rafflesiana Jack. (Color variations N.rafflesiana Jack)

\section{Indeks Nilai Penting (INP)}

Semakin tinggi INP suatu jenis pada suatu kawasan berarti menunjukan semakin dominannya suatu jenis tersebut pada tutupan lahan semak belukar dan hutan sekunder dan terhadap jenis-jenis yang lain dalam suatu kawasan atau komunitas. Semakin kecil nilai INP suatu jenis berarti semakin kecil dominansi jenis tersebut dalam suatu kawasan maupun terhadap jenis lainnya. Penguasaan yang tertinggi pada tutupan lahan semak belukar terdapat pada jenis $N$. ampullaria dan $N$. mirabilis (Lour) Druce. Tigginya nilai INP ini cukup membuktikan mendomnasinya jenis $N$. ampullaria dan $N$. mirabilis (Lour) Druce pada lokasi penelitian serta cocoknya kondisi tempat tumbuh seperti kelembaban udara, suhu udara, sinar matahari, $\mathrm{pH}$ tanah dan ruang tumbuh dengan jenis-jenis lainnya, sehingga melimpahnya dua jenis ini ditemukan. Besarnya nilai INP N. ampullaria dan $N$. mirabilis (Lour) Druce menunjukan adanya pengaruh faktor lingkungan serta tapak tumbuh, sehingga mampu untuk berkompetisi dalam memperebutkan zat hara pada lokasi penelitian. Indeks Nilai
Penting yang paling rendah adalah jenis $N$. rafflesiana Jack rendahnya nilai INP pada jenis ini disebabkan sedikitnya jumlah individu yang ditemukan serta faktor tempat tumbuh yang kurang cocok sehingga jenis ini sedikit ditemukan.

Jenis yang mempunyai peran dalam suatu kawasan hutan dicirikan dengan indeks nilai penting yang tinggi. Jenis yang memiliki indeks nilai penting yang tertinggi menunjukan bahwa jenis tersebut dapat hidup dan berkembang dengan baik dalam suatu kawasan semak belukar dan hutan sekunder di Selakau Timur. Demikian pula sebaliknya jenis yang memiliki indeks nilai penting terkecil atau rendah menunjukan bahwa jenis tersebut hanya dapat hidup dan tumbuh pada suatu habitat tertentu sehingga penyebarannya relatif terbatas. Seperti pada jenis N.rafflesiana Jack yang hanya terdapat pada satu petak pengamatan pada semak belukar.

\section{Keanekaragaman Jenis $(\overline{\boldsymbol{H}})$}

Indek keanekaragaman jenis digunakan untuk mengetahui tingkat keanekaragaman jenis. Keanekaragaman jenis kantong semar pada dua tutupan 
lahan semak belukar dan hutan sekunder dusun Gemuruh masih dalam kategori rendah. Hal ini dikarenakan tidak adanya nilai yang mencapai 1. Indek keanekaragaman jenis dikatan tinggi apabila nilainya mencapai 3. Suatu komunitas yang memiliki nilai $\bar{H}<1$ maka dikatakan komunitas tersebut tidak stabil atau rendah sedangkan jika nilai $\mathrm{H}^{\prime}$ antara 1-3 dikatakan komunitas tersebut stabil atau sedang, sedangkan jika nilai $\bar{H}$ $>3$ maka dikatakan nilai tersebut sangat stabil atau tinggi (Fachrul, 2006). Rendahnya tingkat keanekaragaman jenis kantong semar pada tutupan lahan semak belukar dan hutan sekunder disebabkan masyarakat Selakau Timur umumnya telah merubah vegetasi yang ada disemak belukar menjadi perkebunan sawit.

Pada hutan sekunder masyarakat merubah fungsi lahan menjadi perkebunan dan pertanina, banyak masyarakat di dusun Gemuruh yang bercocok tanam pada hutan sekunder dengan sistem tebang habis bakar hal ini lah yang membuat tumbuhan kantong semar menjadi rusak bahkan mati. Apabila suatu komunitas hanya terdiri dari sedikit jenis dan jumlah individu maupun distribusinya tidak merata maka komunitas tersebut memiliki nilai indeks keanekaragaman jenis yang rendah. Ditambah lagi masyarakat banyak menggunakan kantongnya untuk membuat cetakan kue. Hal ini diperparah minimnya pengetahuan masayarakat tentang jenis kantong semar serta statusnya sehingga masyarakat tidak memeprhatikan aspek lingkungan saat pembukaan lahan.

\section{Dominansi Jenis (C)}

Menurut Odum (1993) indeks dominansi merupakan suatu nilai yang menunjukan pola pemusatan dominansi suatu jenis vegetasi pada suatu komunitas hutan. Hasil perhitungan dari Tabel 4 dapat diketahui bahwa indeks dominansi dari dua tutupan lahan semak belukar dan hutan sekunder Dusun Gemuruh Kecamatan Selakau Timur rendah. Ini disebabkan nilai indeks dominansinya kurang dari 1. Indeks dominansi dikatakan tinggi apabila $\mathrm{C}$ adalah $1 \quad(\mathrm{C}=1)$. Rendahnya indeks dominansi dalam suatu komunitas hutan juga dipengaruhi oleh faktor lingkungan hutan yang menjadi persaingan dalam memperebutkan kebutuhan ruang tempat tumbuh kantong semar. Persaingan yang dilakukan dilakukan oleh organisme-organisme dapat berupa keaktifan dalam memperebutkan kebutuhan ruang (tempat), makanan, unsur hara, air, intensitas cahaya, udara serta faktor-faktor lainnya sebagai sumber daya yang dibutuhkan oleh tiap-tiap organisme untuk mempertahankan hidup dan pertumbuhannya.

Dari hasil diatas dapat disimpulkan tingkat dominansi dari komunitas kantong semar yang ada pada tutupan lahan semak belukar dan hutan sekunder rendah, hal ini disebabkan oleh tingkat komunitas pada jenis kantong semar tidak ada yang mendominasi. Menurut Indriyanto (2006) bahwa pertumbuhan dan perkembangan yang cepat terjadi pada kondisi lingkungan yang optimal dengan adanya kesesuain habitat. Dengan demikian kehadiran spesies yang dominan merupakan sebuah hasil yang baik dari penyesuaian. 


\section{Kelimpahan Jenis (e)}

Indek kelimpahan jenis biasanya dipengaruhi oleh besarnya nilai keanekaragaman suatu jenis dan jumlah seluruh jenis, artinya semakin tinggi kelimpahan jenis maka penyebaran akan semakin merata dalam kawasan tersebut begitu juga sebaliknya. Indek kelimpahan jenis biasanya dipengaruhi oleh besarnya nilai keanekaragaman suatu jenis dan jumlah seluruh jenis, artinya semakin tinggi kelimpahan jenis maka penyebaran akan semakin merata dalam kawasan tersebut begitu juga sebaliknya. Indeks kelimpahan jenis berkisar antara0-1, jika e $>1$, maka seluruh jenis yang ada memiliki kelimpahan yang sama atau merata, sedangkan jika e $<1$ maka seluruh jenis yang ada kelimpahannya tidak merata. Dari hasil perhitungan Tabel 5 dapat di ketahui bahwa indeks kelimpahan jenis (e) pada dua tutupan lahan semak belukar dan hutan sekunder tidak merata hal ini disebabkan tidak adanya nilai yang mencapai 1. Nilai kemerataan dikatakan relatf merata atau jumlah masing-masing jenis sama jika nilai e nya mencapai 1 sedangkan jika kemerataanya 0 maka nilainya dikatakan jenis tersebut rendah.

Sehingga dapat ditarik kesimpulan bahwa pada lokasi penelitian Dusun Gemuruh Kecamatan Selakau Timur kemerataanya relatif rendah. Secara umum indeks kelimpahan jenis. Hal ini disebabkan bahwa kondsi lingkungan ditutupan lahan semak belukar dan hutan sekunder cenderung untuk membatasi berlimpahnya jenis tertentu, dengan demikian mempersulit jenis untuk menambah populasi. Namun saat ditemukan pada lokasi penelitian ada kecendrungan bahwa jenis $N$. mirabilis (Lour) Druce lebih melimpah dibandingkan jenis $N$. gracilis Korth hal ini disebabkan N. mirabilis (Lour) Druce lebih cepat berbunga dan berbuah sehingga regenerasi yang berasal dari biji berjalan dengan baik. Menurut Hariyadi (2013), N. mirabilis (Lour) Druce mampu tumbuh diberbagai tempat tumbuh baik di areal ternaungi maupun areal terbuka dan memiliki persebaran yang luas.

\section{Penyebaran Kantong Semar}

Penyebaran kantong semar dihitung berdasarkan hasil analisis menggunakan indek morisita. Hasil perhitungan indeks morisita (Id) digunakan untuk membandingkan komunitas yang menghuni atau mendiami pada habitathabitat yang berlainan selama selang waktu tertentu. Dari hasil perhitungan dapat di ketahui bahwa pada tutupan lahan semak belukar pola penyebaran kantong semar bersifat berkelompok. Hal ini dikarenakan nila Id nya lebih besar dari 1 $(4,673)$. Sedangkan pada tutupan lahan hutan sekunder penyebaran kantong semar ini bersifat seragam hal ini disebabkan nilai Id nya kurang dari 1. Dari perhitungan yang didapat dilapangan pada tutupan lahan semak belukar jenis $N$. ampullaria, dan N. mirabilis (Lour)Druce penyebarannya dilapangan secara berkelompok. Hal sejalan dengan penelitian yang dilakukan oleh Oktaviana (2018) pada kawasan hutan tanaman industri PT. Bhatara Alam Lestari Kabupaten Mempawah bahwa $N$. ampullaria pada kawasan tersebut pola penyebarannya sama yaitu secara 
berkelompok. Keberadaan jenis secara berkelompok disebabkan oleh hubungan yang saling membutuhkan sehingga mengurangi kompetisi mereka. Sementara itu untuk jenis $N$. gracilis Korth penyebarannya seragam dan $N$. rafflesiana Jack pola penyebarannya secara acak hal ini dsebabkan karena pada petak pengamatan yang ditemukannya $N$. rafflesiana Jack dan nilai Id $=1$ serta hal ini diduga karena tempat tumbuh yang cocok untuk jenis tersebut. Hal ini karena individu memiliki kencenderungan untuk hidup berkelompok dan mencari kondisi lingkungan yang cocok dengan kebutuhan hidupnya. Sedangkan untuk jenis $N$. ampullaria, dan N. mirabilis (Lour) Druce keberadaan jenis tersebut secara berkelompok hal ini disebabkan oleh hubungan yang saling membutuhkan sehingga mengurangi kompetisi diantara mereka akan tetapi membuat setiap jenis menjadi lebih baik terhadap jenis lain.

\section{Lingkungan Habitat Kantong Semar (Nepenthes spp.)}

Berdasarkan tempat tumbuhnya kantung semar dapat dibagi menjadi 3 yaitu dataran rendah, dataran menengah dan dataran tinggi. Hasil pengukuran ketinggian petak ukur tempat tumbuh kantong semar pada lokasi penelitian dapat dilihat pada Tabel 2.

Tabel 2. Pengukuran Ketinggian Tempat Tumbuh Kantong Semar Pada Tutupan Lahan Semak Belukar dan Hutan Sekunder Dusun Gemuruh Kecamatan Selakau Timur. (Height of Place Growth Measurement Nepenthes Land Cover of Secondary Shrub and Forest Shrubs in Gemuruh, East Selakau Sub-district)

\begin{tabular}{|c|c|}
\hline Altitude ( $\mathrm{m} \mathrm{dp}$ & Habitat \\
\hline 73 & Semak Belukar \\
\hline 72 & Semak Belukar \\
\hline 71 & Semak Belukar \\
\hline 73 & Semak Belukar \\
\hline Rata - rata & \\
\hline 81 & Hutan Sekunder \\
\hline 78 & Hutan Sekunder \\
\hline Rata - rata & \\
\hline $\begin{array}{l}\text { Dari hasil pengukuran yang } \\
\text { dilakukan pada lokasi penelitian pada } \\
\text { tutupan lahan semak belukar dan hutan } \\
\text { sekunder dapat disimpulkan bahwa } \\
\text { semua jenis kantong semar yang } \\
\text { ditemukan di lokasi penelitian berada } \\
\text { pada dataran rendah. Hal ini karena } \\
\text { ketinggian tempat tumbuh kantong } \\
\text { semar di bawah } 300 \text { m dpl. Ketinggian } \\
\text { tempat penelitian rata-rata berkisar }\end{array}$ & $\begin{array}{l}\text { Berdasarkan tempat tumbuhnya dapat } \\
\text { dibagi menjadi } 3 \text { yaitu dataran rendah } \\
(0-300 \mathrm{~m} \mathrm{dpl}) \text { dataran menengah }(300- \\
700 \mathrm{~m} \mathrm{dpl}) \text { dan dataran tinggi (> } 700 \mathrm{~m} \\
\text { dpl). Berdasarkan pengukuran yang } \\
\text { dilakukan pada lokasi penelitian di } \\
\text { Dusun Gemuruh Kecamatan Selakau } \\
\text { Timur lokasi penelitian masuk dalam } \\
\text { kategori dataran rendah. Hal ini } \\
\text { dikarenakan rata- rata ketinggian tempat }\end{array}$ \\
\hline
\end{tabular}


lokasi penelitian berada dibawah $300 \mathrm{~m}$ dpl.

Hal ini sesuai dengan penelitian yang dilakukan oleh Emo Sintaro (2016) di Bukit Benua Kabupaten Kubu Raya bahwa $N$. ampullaria ditemukan pada ketinggian 25,1 - 73,37 $\mathrm{m}$ dpl. Meskipun keempat jenis yang ditemukan masih masuk dalam kategori dataran rendah tapi tiga jenis yang ditemukan pada semak belukar tidak ditemukan pada hutan sekunder.

\section{KESIMPULAN}

1. Hasil penelitian menunjukan bahwa, kantong semar yang ditemukan di Dusun Gemuruh Kecamatan Selakau Timur di tutupan lahan semak belukar terdiri dari empat jenis kantong semar, yaitu $N$. ampullaria, N. mirabilis (Lour) Druce, N. gracilis Korth dan $N$. rafflessiana dan hutan sekunder ditemukan satu jenis yaitu N. mirabilis (Lour) Druce. dan jumlah nilai keanekaragaman jenis pada semak belukar 0,2677 dan hutan sekunder 0,0555 sedangkan indeks dominansi dari jenis $N$. ampullaria 0,02389, N. mirabilis $0,01015, N$. gracilis 0,00032 dan $N$. rafflessiana 0,00002 dan nilai indeks dominansi $N$. mirabilis pada hutan sekunder 0,0555 .

2. Hasil penelitian kondisi tempat tumbuh yang didapatkan pada tutpan lahan semak belukar menunjukan bahwa kantong semar bisa hidup pada kondisi tempat tumbuh dengan suhu udara rata-rata $25,75^{\circ} \mathrm{C}$, kelembaban udara rata-rata $69,33 \%$, suhu tanah rata-rata $27,88^{\circ} \mathrm{C}, \mathrm{pH}$ tanah 6 serta intensitas cahaya 3, 48 lux sedangkan pada hutan sekunder menunjukan bahwa kantong semar bisa hidup pada kondisi tempat tumbuh dengan suhu udara rata-rata $22,08^{0} \mathrm{C}$, kelembaban udara rata-rata $79,42 \%$, suhu tanah rata-rata 26,00 ${ }^{0} \mathrm{C}, \mathrm{pH}$ tanah 6, 5 serta intensitas cahaya 2,55 lux.

\section{DAFTAR PUSTAKA}

Dino. 2016. Study of Diversity and Conditions of The Place of Growing Pitcher Plant (Nepenthes Spp ) in Sebedang Lake The District of Sebawi Sambas Regency.Jurnal Hutan Lestari. Pontinaka. 4 (3) : 371 - 379

Fathul A, Adi K, Teten R. 2007. Kantong Semar (Nepenthes sp.) Di Hutan Sumatera, Tanaman Unik Yang Semakin Langka. Prosiding Ekspose Hasil-Hasil Penelitian, 2007. Hal. 174.

Ferianita FM. 2007. Metode Sampling Bioteknologi. Jakarta. PT. Bumi Aksara.

Firstantinovi ES, Karjono. 2006. Kami Justru Mendorong. Artikel Majalah edisi 444 November 2006

Handayani T. 2008. (Nepenthes spp.) Koleksi Kebun Raya Bogor yang berpotensi sebagai tanaman hias. Warta Kebun Raya. Bogor. 3(1):26-31.

Hariyadi. 2013. Inventarisasi Tumbuhan Kantong Semar (Nepenthes spp.) Di Lahan Gambut Bukit Rawi Kalimantan Timur. Jurnal Biospecies. 6.(1) $24-27$.

Indriyanto. 2006. Ekologi Hutan. Bumi. Bumi Aksara. Jakarta. 208p 
JURNAL HUTAN LESTARI (2019)

Vol. 7 (2) : 844 - 856

Michael P. 1994. Metode Ekologi Untuk Penyelidikan Ladang Dan laboratorium Universitas Indonesia. Jakarta

Odum EP. 1993. Dasar-dasar ekologi.Terjemahan oleh Tjahjono Samingan dari buku Fundamentals of Ecology.Yogyakarta : Gadjah Mada University Press

Septiani O. 2018. The Diversity of Kantong Semar (Nepenthes spp) in Industrial Plantation Forest Areas Sustainable Natural PT. Bhatara Alam Lestari Mempawah district of West Kalimantan. Jurnal Hutan Lestari. Pontinaka. $6(4): 733-741$

Sintaro E. 2016. Species Diversity and Distribution Pattern of Nepenthes spp In Bukit Benua, Districk of Kuburaya. Jurnal Hutan Lestari. Pontinaka. 4 (1) : 109 - 11 